\title{
Colorectal quotations
}

Like all my colleagues at St Mark's I am fascinated by the gastrointestinal tract, its mysteries, its challenges and the many unconquered diseases that afflict it. I am also a surgeon; therefore I confess that, when making the collection that emerged as the Oxford Dictionary of Medical Quotations, ${ }^{1}$ there was a degree of bias towards the gut and the knife. Here I offer some of the fruits of my literary explorations on coloproctology and kindred matters.

Coloproctology is inseparable from stools, and the great medical missionary and scientist Denis Burkitt (1911-1993) took a passionate interest in this material — to the extent of displaying photographs of 'the perfect stool' to his neighbours at grand dinners. 'Big stools,' he declared, 'small hospitals, small stools, big hospitals'. Although Burkitt's enthusiasm sometimes led him to overstate the case, he deserves credit for causing the medical profession to think seriously about the consequences of fibre and its lack. Another product of the intestines is gas, and every gastroenterological physician or surgeon knows that the sound of flatus passed at the right time can be sweeter to the ear than a Mozart symphony. The best description in the modern literature comes not from a doctor but from the journalist and naturalist Gavin Maxwell (1914-1969) recording the ending of his own postoperative ileus: 'Then it came, thunderous, earthshaking, the longest, loudest and most superbly stupendous fart that I have ever heard in my life, a sound of such magnificent and prolonged volume as to appear utterly beyond human capability'.

Even in modern times surgery can be dangerous, but the historical record is rich in illustrations. The English dramatist John Lyly (1554-1606) wrote simply that 'The wound that bleedeth inward is most dangerous' — a good lesson for any young coloproctologist to heed. And Lord Moynihan's (1865-1936) observation that 'Every operation is an experiment in bacteriology' might make us wonder that any of our patients survive our efforts. The US surgeon Rudolph Matas (1860-1957) remarked that the master surgeon is a person of many qualities - 'a man of mind, a man of thought, a man who knows his province, the human body, as a whole and not only one of its parts'.

What of the less diligent? It was another US surgeon, William J Mayo (1861-1939), who castigated professional

Northwick Park and St Mark's NHS Trust, Watford Road, Harrow HA1 3UJ, UK E-mail: pmcdo69277@aol.com colleagues thus: 'The examining physician often hesitates to make the necessary examination because it involves soiling the finger'. Whether he was referring to physicians in the British sense (non-surgeons) or to clinicians in general may be debated. In colorectal work today, surgeons and physicians differ little in their diagnostic methods. When it comes to treatment, perhaps the latter are less impatient to intervene, heeding the old proverb concerning the healing powers of 'nature, time and patience'. As for our immediate co-workers the anaesthetists, we surgeons tend to hope they will remain cheerful and cooperative and serve the patients up respectfully as William T Morton (18191868), the founder of ether anaesthesia in the US, did for John Warren Collins on 16 October 1846 with 'Your patient is ready, Sir'.

St Mark's Hospital prides itself on expertise built up over nearly 170 years and experts must be philosophical when made the butt of jealous humour. 'An expert', according to a recent US Attorney General Ed Meese, 'is someone who is more than fifty miles from home, has no responsibility for implementing the advice he gives, and shows slides'. An essential component of the work of St Mark's is research. This activity too has attracted mockery - for example, the assertion of Thorstein Veblen (18571929) that 'The outcome of any serious research can only be to make two questions grow where only one grew before'. Statistics come in for a good share of the abuse. One of the less familiar aspersions is that of the writer Rex Stout (1886-1975): 'There are two kinds of statistics, the kind you look up and kind you make up'. More seriously, Francis Heed Adler (1895-1975) declared scientific work an essential part of training: 'The faculties developed by doing research are those most needed in diagnosis'.

The moral and philosophical background of our work is always intriguing. Though in the past surgeons must have killed a high proportion of their clients, they somehow retained the regard of their communities. One of the most powerful quotations on surgical failure comes from René Leriche (1879-1956): 'Every surgeon carries about him a little cemetery, in which from time to time he goes to pray, a cemetery of bitterness and regret, of which he seeks the reason for certain of his failures.' Whatever our branch of medicine, we all make errors. The US surgeon Chris Lillehei put it nicely when he said, 'Good judgment comes from experience; experience comes from bad judgment'. 
With all this in mind we must never forget why we are in the game in the first place. One of my favourite pronouncements on this matter comes from the great Chicago professor of surgery John Benjamin Murphy (1857-1916): 'The patient is the center of the medical universe around which all our works revolve and towards which all our efforts tend'. This philosophy is not, of course, confined to the medical profession. Indeed, the declared aim for the British National Health Service to become patient-centred rather than doctor-centred marks a doubt about doctors' motives in the past. Politicians and administrators have become less accepting of the doctors' traditional assertion that, to attract the best, brightest and most caring young people, the profession must be in charge and autonomous. Multidisciplinary and multiprofessional teams have their merits, but shared decision-making can be taken too far. It was the public health physician Professor RJ Lilford who wisely wrote two years ago, 'It would be wrong to think that, as medicine loses its professional hegemony, the whole of health care will dissolve into amorphous and harmonious islands of multidisciplinary practice floating in an egalitarian sea'.
The current notion of doctors as cogs in the machine does not sit well with a requirement for leadership by example, by knowledge and by hard work. The US physician and educator A McGhee Harvey wrote that Each of us should strive to rise above the routines of the daily ward round and to see in every patient an opportunity not only to serve mankind in the best tradition of medical excellence, to add to the store of medical knowledge'.

Let the last word come from a man whose signature happens to appear on the Glasgow University diploma of my great-grandfather George Bruce McDonald. This was Joseph Lister (1827-1912). Before proceeding south from Scotland to pursue his illustrious career, Lister had offered the following credo for students and doctors as they went through bad times as well as good: 'It is our proud office to tend the fleshy tabernacle of the immortal spirit, and our path, if rightly followed, will be guided by unfettered truth and love unfeigned'.

\section{REFERENCE}

1 McDonald P. Oxford Dictionary of Medical Quotations. Oxford: Oxford University Press, 2003 